\title{
Effect of a Boundary Layer Leak Slot on Improving the Test Section Flow Quality in an Open Return Meteorological Wind Tunnel
}

\author{
By \\ Nobuyuki Kinoshita* \\ Physical Meteorology Research Department, Meteorological Research Institute, Tsukuba, Ibaraki, 305-0052 Japan
}

(Received July 7, 2004; Revised March 2, 2005; Accepted April 22, 2005)

\begin{abstract}
A boundary layer leak slot is devised to improve flow quality in an open return wind tunnel and is tested in the large meteorological wind tunnel of the Meteorological Research Institute. The feature of the slot is that the forcible exhaust, as adopted in many automobile wind tunnels, is not used. The most effective width for improvement is determined to be $40 \mathrm{~cm}$, by an experiment in which the slot width defined as the streamwise opening length is varied from $0 \mathrm{~cm}$ to $100 \mathrm{~cm}$. Installing the boundary layer leak slot upstream of the test section remarkably improved the wind velocity uniformity in the cross-direction to the centerline of the wind tunnel in the upper reaches of the test section. The improvement is not clear in the lower reaches, however. The deterioration of uniformity downstream was caused by irregular floor-surface roughness resulting from long-time use. It can be concluded that the boundary layer leak slot is an effective low-cost method of improving flow quality in an open return wind tunnel.
\end{abstract}

\section{Introduction}

In wind tunnel experiments, uniformity of wind velocity in the test section, especially cross-direction to the centerline, is an important factor related to accuracy and reliability. Wind velocity near the surface must be uniformly distributed, especially in experiments where there is no choice but to use much-reduced landform models with small undulation, or in experiments investigating the wind on the sea around an island. Therefore, wind tunnels are carefully designed and constructed so that the flow is uniform (Barlow et al., 1999). However, roughly finished floors and floors damaged by long-time use often develop a boundary layer of non-uniform depth and result in non-uniform wind velocity distribution near the floor surface. In such situations, measures to improve flow quality are necessary.

\footnotetext{
* Present affiliation: Administration Division, Observations Department, Japan Meteorological Agency, 1-3-4 Ohtemachi Chiyoda-ku Tokyo, 100-8122 Japan

(C) 2006 by the Japan Meteorological Agency / Meteorological Research Institute
}

The purpose of the present study, therefore, is to find and examine an effective measure of improving flow quality.

The usual method of rectifying this problem is to grind the floor surface in the wind tunnel. However, this method is expensive because it is difficult to make the curved surface of the contraction smooth and completely uniform, and because the extensive surface from the fan to the end of the test section must be made smooth even for open return wind tunnels. Furthermore, the area needed to be made smooth is even more extensive for closed return wind tunnels. Another solution is to discharge the boundary layer upstream of the test section. This method, called the boundary layer suction system, has been used in many automobile wind tunnels. In Japan, for example, Nissan's model-scale wind tunnel (Ishihara, 2002), Toyota's model-scale wind tunnel, Mitsubishi Motor's full-scale wind tunnel, and the Railway Technical Research Institute's large-scale low-noise wind tunnel are equipped with suction systems. The boundary layers in these wind tunnels are forcibly sucked out because they are closed return wind tunnels. In contrast, forcible suction may not be required for an open return wind tunnel: the fan pushes the air into the tunnel, and the atmospheric pressure in the tunnel is higher 


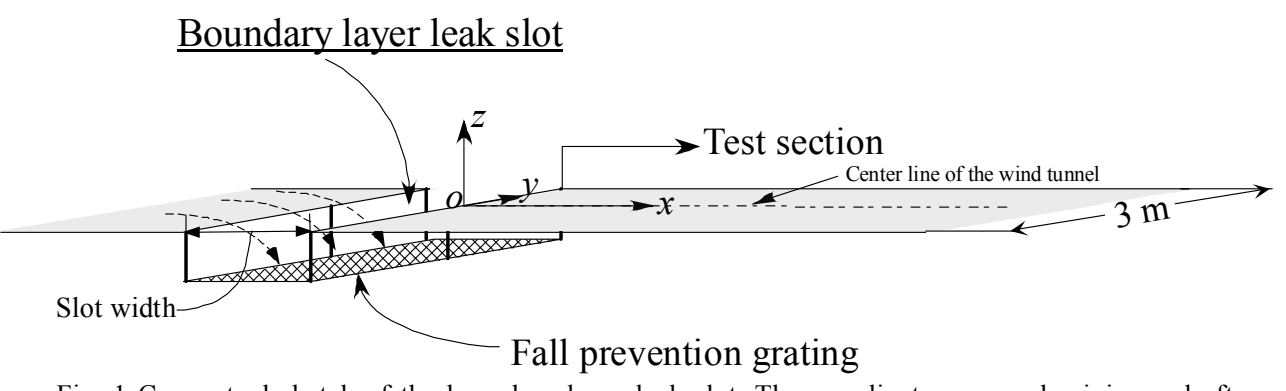

Fig. 1 Conceptual sketch of the boundary layer leak slot. The coordinate axes and origin used after section 2 are indicated by $x, y, z$, and $O$.

than that on the outside. With the installation of a slot such as the one illustrated in Fig. 1, the near-surface layer with non-uniform wind velocity distribution is expected to leak out. Therefore, the most economical way may be to discharge the boundary layer of open return wind tunnels through a slot upstream of the test section, if the slot works well without forcible suction.

In the present paper, a boundary layer leak slot is installed in the large meteorological wind tunnel of the Meteorological Research Institute (MRI), and its effect is examined. The following sections describe how the test section flow is measured before the leak slot installation, and how the most effective slot width is determined and installed. Finally, the test section flow is measured again, revealing a remarkable improvement.

\section{Flow quality in the test section of MRI's large meteorological wind tunnel}

\subsection{Description of the wind tunnel}

Figure 2 depicts the basic structure of MRI's large meteorological open return wind tunnel as a vertical section. The air blown from the rear returns to the fan through the indoor surroundings $10 \mathrm{~m}$ high, $12 \mathrm{~m}$ wide, and $54 \mathrm{~m}$ long. The test section is $3.0 \mathrm{~m}$ wide, $2.0 \mathrm{~m}$ high, and $18.0 \mathrm{~m}$ long, and the contraction ratio is six. The floor of the test section consists of six $3 \mathrm{~m}$ long panels, the heights of which can be lowered to substitute a turntable. The floor surface is painted black for antireflection when using a laser beam in flow visualization experiments and a laser Doppler velocimeter (LDV). This wind tunnel was previously described by Uchida (1980) and Kinoshita (2003).

\subsection{Measuring wind velocity}

Two horizontal wind components in the test section are measured using the LDV (BSA F60 made by DANTEC) attached to the traverser. The measurement error of the LDV is within $0.1 \%$ in the catalog. Alignment of the LDV is adjusted within $0.1^{\circ}$ by using a laser-leveling instrument (AL-TYE3J made by TJM Design) that projects a horizontal line and a vertical line on the wall, and a straight line on the ceiling and the floor. Tracer particles are released from the fog generator placed upstream of the wind tunnel fan to decrease particle density fluctuation. Since the LDV generates a velocity signal only when a tracer particle passes through the measuring volume, the measured data are resampled at $100 \mathrm{~Hz}$ by linear interpolation. The resampling period is 30 seconds, which can be considered long enough to obtain a stable statistic because the average and standard deviation are almost equal to those for 30 seconds when the sampling period exceeds 15 seconds in the experiment.

The coordinates are taken as presented in Fig. 1. $U$ and $V$ are the mean velocity components in the $x$ and $y$ directions, and $u$ is the fluctuating velocity component in the $x$ direction. $\sigma_{u}$ represents the standard deviation of $u$. The upwind end of the test section is chosen to be $x=0$. The center of the width of the test section is made to be $y=0$. The rotational frequency of the fan is adjusted so that the wind velocity at the point of $x=0.43 \mathrm{~m}, y=0 \mathrm{~cm}$, and $z=70 \mathrm{~cm}$ is $5.0 \mathrm{~m} / \mathrm{s}$. This wind velocity is chosen because the ceiling height of the test section is tilted up to achieve the zero streamwise static pressure gradient for the wind velocity of $5 \mathrm{~m} / \mathrm{s}$, and the wind velocity around $5.0 \mathrm{~m} / \mathrm{s}$ is used frequently in the wind tunnel. Measurements at heights of 5, $10,30,50$ and $70 \mathrm{~cm}$ are made from $y=-100$ to $+100 \mathrm{~cm}$ with $20 \mathrm{~cm}$ intervals at $x=0.43,2.0,5.0,8.0,11.0$ and $15.0 \mathrm{~m}$. The measurement ranges of $x$ and $z$ are same as the movable range of the LDV on the traverser. The $y$ range is the same as the turntable diameter.

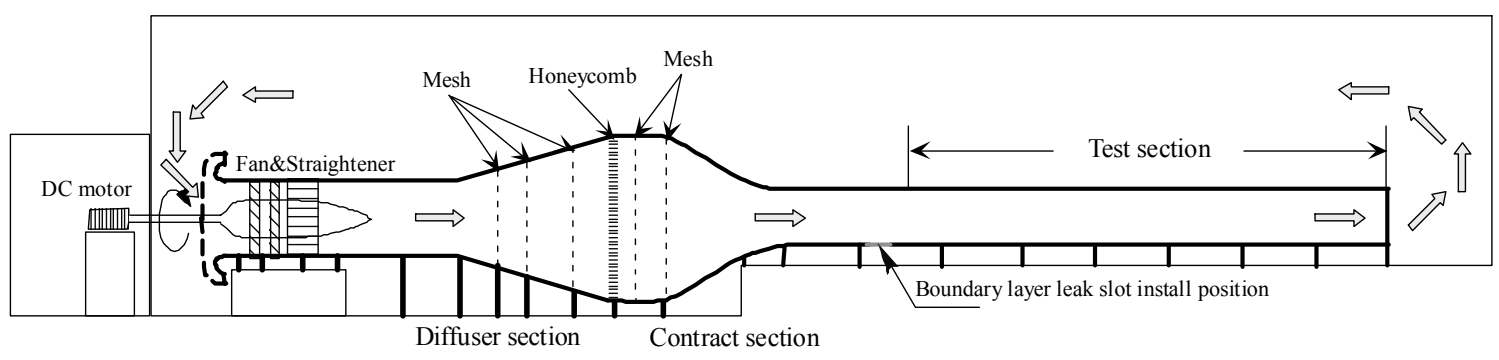

Fig. 2 MRI's large meteorological wind tunnel. 

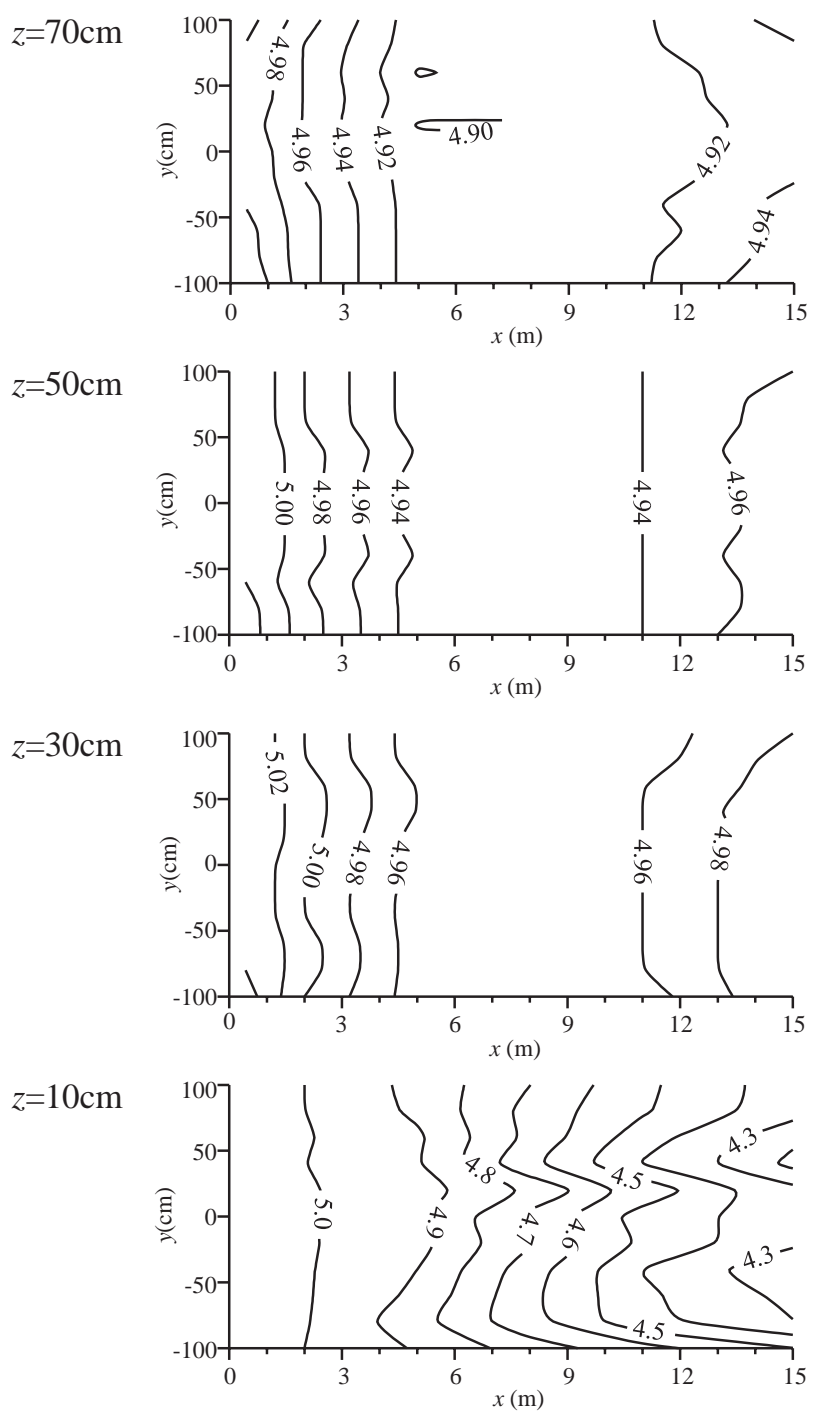

$z=5 \mathrm{~cm}$
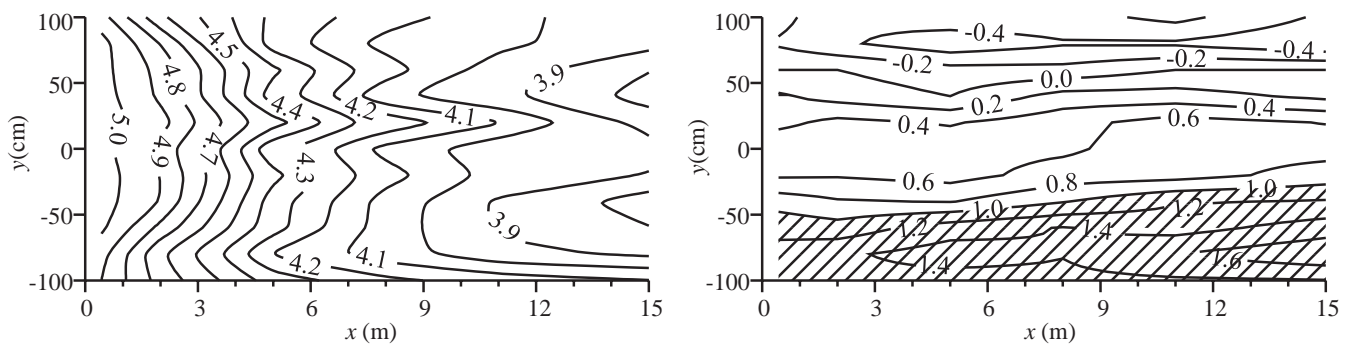

Fig. 3 Distributions of $U$ (left column panels) and the mean flow deflection angle $D$ (right column panels) at heights of $70 \mathrm{~cm}, 50 \mathrm{~cm}, 30 \mathrm{~cm}, 10 \mathrm{~cm}$, and $5 \mathrm{~cm}$ before the installation of the boundary layer leak slot. The values on the contours for $U$ are in $\mathrm{m} / \mathrm{s}$. Those for $D$ are in degree. The areas of $D \geq 1.0^{\circ}$ are hatched.

\subsection{Flow quality in the test section}

Figure 3 presents the distributions of $U$ and the mean flow deflection angle before the installation of the boundary layer leak slot at the heights of 70, 50, 30, 10 and $5 \mathrm{~cm}$. At the height of $5 \mathrm{~cm}, U$ is larger along the line of $y=20 \mathrm{~cm}$ than in the circumference. Low wind velocity areas are found along the line of $y=40 \mathrm{~cm}$ and that of $y=-60 \mathrm{~cm}$ in the area of $x \geq 9 \mathrm{~m}$. At a height of $10 \mathrm{~cm}$, the distribution of $U$ is more monotonous in the area of $x \leq 3 \mathrm{~m}$ than at the height of $5 \mathrm{~cm}$, but it becomes similar to that at the height of $5 \mathrm{~cm}$ as $x$ increases. The distributions of $U$ over the height of $30 \mathrm{~cm}$ are uniform in the $y$ direction but slightly lower as $x$ increases. The depth of the boundary layer, defined by the height at which the wind velocity becomes $95 \%$ of the free stream velocity (i.e., $U$ at $x=0.43 \mathrm{~m}, y=0$, and $z=70 \mathrm{~cm}$ ), reaches $5 \mathrm{~cm}$ at $x=3 \mathrm{~m}$. The depth exceeds $10 \mathrm{~cm}$ in the whole region of $x \geq 8 \mathrm{~m}$, though the development of the boundary layer is unequal for the $y$ direction. Therefore, the boundary layer depth cannot be less than $10 \mathrm{~cm}$ for $x \geq 8 \mathrm{~m}$. The value of $U$ at $z=5 \mathrm{~cm}$ varies from $4.60 \mathrm{~m} / \mathrm{s}$ to $4.94 \mathrm{~m} / \mathrm{s}$ 

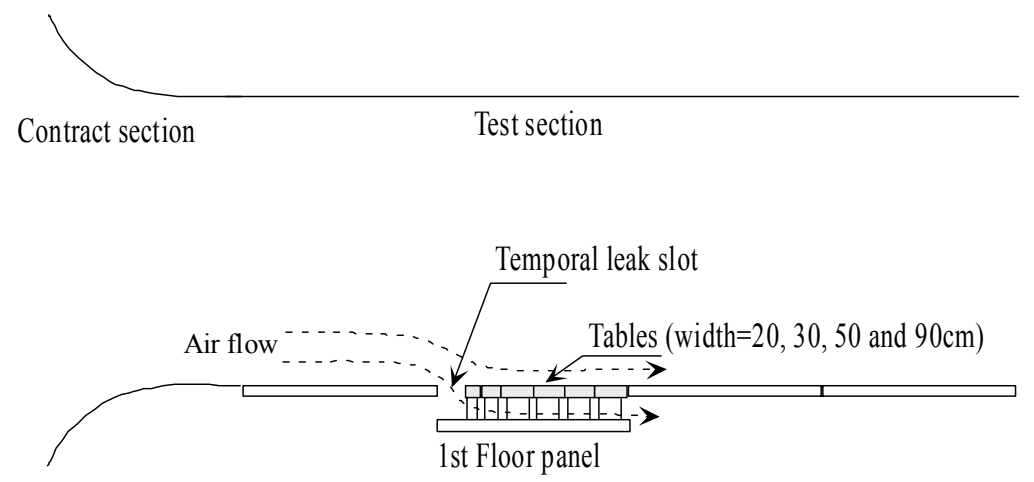

Fig. 4 Experimental setup for slot-width determination.

on the line from $y=-100$ to $+100 \mathrm{~cm}$ at $x=2.0 \mathrm{~m}$ (see Fig. 7). The maximum deviation from the average of $4.80 \mathrm{~m} / \mathrm{s}$ on this line is $-4.2 \%$.

Large values of $D$ exceeding $1^{\circ}$ are found in the layer lower than $30 \mathrm{~cm}$ and in part of the layer at the height of $70 \mathrm{~cm}$. Most of the values of $D$ in the layers over $30 \mathrm{~cm}$ are between $0.5^{\circ}$ and $0.8^{\circ}$, indicating that the flow above the height of $30 \mathrm{~cm}$ is in almost the same direction but not along the centerline of the wind tunnel. The flow deflection angles around the centerline are almost $0.5^{\circ}$ at every height. However, the angles in the area apart from the centerline differ with height. This discrepancy is probably due to the effect of the walls.

The non-uniformity of $4 \%$ in the wind velocity at the height of $5 \mathrm{~cm}$ and the deflective flow may become serious problems in experiments with much reduced landform models. The small corrugation on these models makes the detection of the landform effect on the flow very difficult when the approach flow is not uniform. In such experiments, a low boundary layer is required because the height of the boundary layer must be adjusted to the scale. It is difficult to place the roughness elements so that the non-uniformity may fade away because the use of large roughness elements and the dense arrangement of roughness elements lead to a high boundary layer. Therefore, measures to improve air flow quality are necessary.

\section{Boundary layer leak slot and its effect}

\subsection{Determining the slot width}

The mean flow deflection is due to the remains of rotational flow caused by the fan and/or the slight fault of a straightener angle. In contrast, the non-uniform flow near the floor surface is caused by the boundary layer that developed unequally in the upper reach of the wind tunnel. Indeed, some swelling made by welding is found here and there in the contraction that should have a smooth surface. On the floor surface of the test section, the paint has peeled off in some locations and is thick in other locations. These areas develop an unequal boundary layer in the test section. Before the installation of the boundary layer leak slot, its most effective width should be determined.

Defining the slot width as the streamwise opening length as illustrated in Fig. 1, the most effective slot width is determined by the experiment. As revealed in Fig. 4, a temporary slot is made by arranging the vinyl chloride tables on the lowered floor panel from $x=0$ to $3 \mathrm{~m}$. The heights of the tables are $23 \mathrm{~cm}$, and tables of 20,30,50 and $90 \mathrm{~cm}$ widths are used. The differences in the wind velocity distribution caused by slot width change are examined. The slot width is varied from $0 \mathrm{~cm}$ to $100 \mathrm{~cm}$ by changing the combination of the tables. The $0 \mathrm{~cm}$ slot width is made by arranging the tables with no space between them. The measurements of $U$ at a height of $5 \mathrm{~cm} 1.0 \mathrm{~m}$ downwind from the lee side end of the slot are made from $y=-100$ to $+100 \mathrm{~cm}$ with $20 \mathrm{~cm}$ intervals. The measurements are made for the three values of $U_{f}=1.0,5.0$ and $10.0 \mathrm{~m} / \mathrm{s}$. $U_{f}$ is kept constant by changing the rotational frequency $r$ of the fan. The measurements for the slot width of $0 \mathrm{~cm}$ is omitted for $U_{f}=10.0 \mathrm{~m} / \mathrm{s}$.

The $y$-directional uniformity on the line of $x=X$ and $z=Z$ can be evaluated by

$$
E_{(X, Z)}=\frac{1}{\bar{U}_{(X, Z)}} \sqrt{\frac{1}{N} \sum_{y=-100 c m}^{+100 c m}\left\{U_{(X, y, Z)}-U_{(X, Z)}\right\}^{2}} \text {, }
$$

where $U_{(X, y, Z)}$ and $\bar{U}(X, Z)$ are $U$ at the point $(X, y, Z)$ and the average of $U_{(X, y, Z)}$ on $y$, and the value of $N$ is 11 . The changes of $E$ and the average of $\sigma_{u} / U$ with the increase of slot width are depicted in Fig. 5. $E$ is almost constant at $4 \%$ for $U_{f}$ of $1.0 \mathrm{~m} / \mathrm{s}$. However, when the slot width is from $20 \mathrm{~cm}$ to $50 \mathrm{~cm}$ and $U_{f}$ is $5.0 \mathrm{~m} / \mathrm{s}, E$ becomes $1 / 10$ of the value without slot. When $U_{f}$ is $10.0 \mathrm{~m} / \mathrm{s}, E$ becomes small with the increased slot width but is larger than that for $U_{f}$ $=5.0 \mathrm{~m} / \mathrm{s}$. The average of $\sigma_{u} / U$ for $U_{f}=1.0 \mathrm{~m} / \mathrm{s}$ is almost constant except when the slot width is $100 \mathrm{~cm}$. In cases in which $U_{f}$ is $5.0 \mathrm{~m} / \mathrm{s}$ or $10.0 \mathrm{~m} / \mathrm{s}$, the average of $\sigma_{u} / U$ is minimized when the slot width is $40 \mathrm{~cm}$ or $50 \mathrm{~cm}$. When both $E$ and the average of $\sigma_{u} / U$ are minimal, the slot is the most effective because the effective slot is expected to leak the layer with non-uniform wind velocity distribution without disturbing the flow. Thus, it is fixed to make the slot of $40 \mathrm{~cm}$ width.

In Fig. 5, the values of $r$ are compared with $r_{0}$, the rotational frequency when the slot width is $0 \mathrm{~cm}$. It is determined that $r$ must be increased $2 \%$ to keep $U_{f}$ constant 

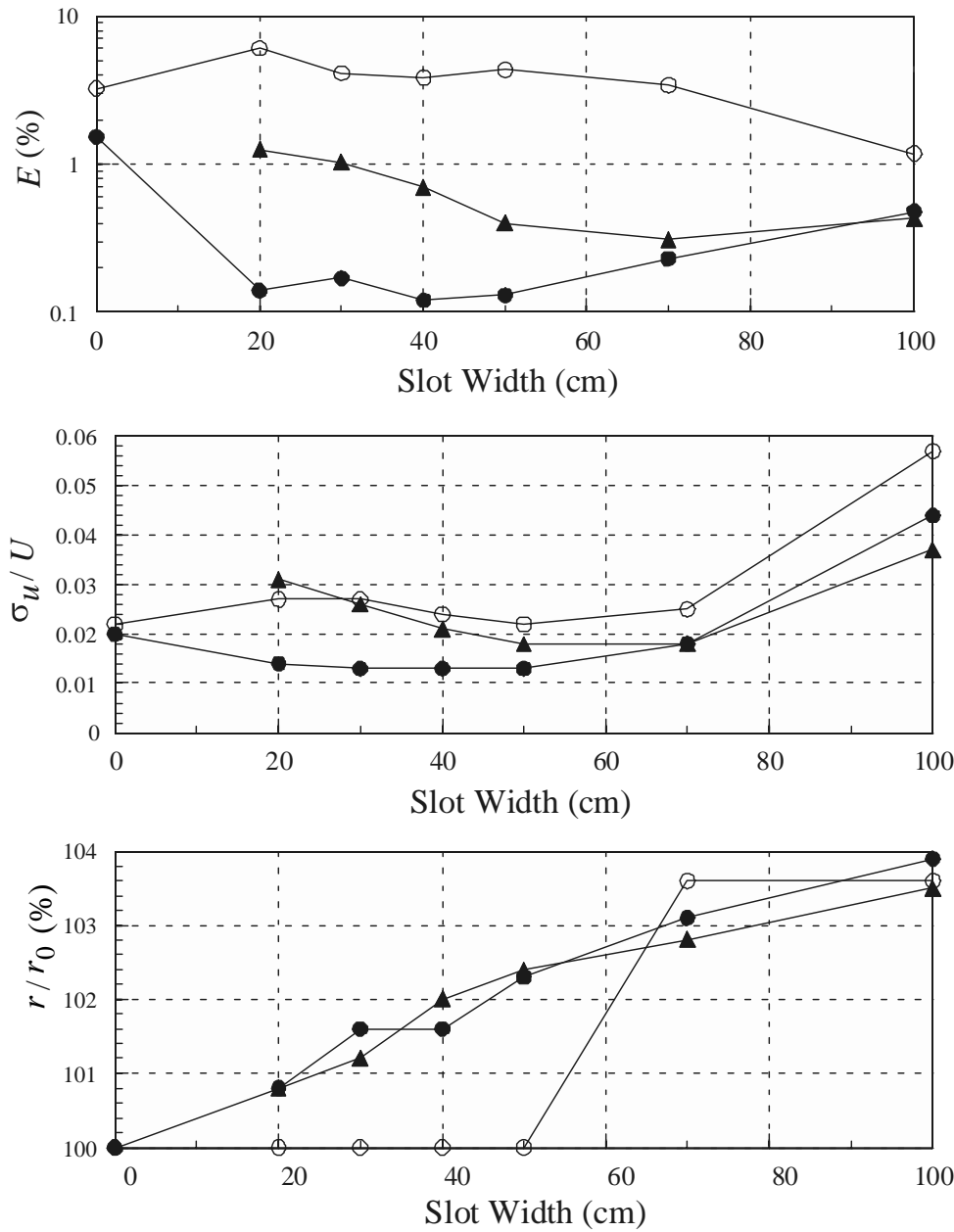

Fig. 5 Variation of $E$, the average of $\sigma_{u} / U$, and the rotational frequency ratio $r / r_{0}$ versus slot width. The open circles, filled circles, and filled triangles indicate free flow velocities of $1.0,5.0$, and $10.0 \mathrm{~m} / \mathrm{s}$. The values of $E$ and $r / r_{0}$ are presented in percentage.

when the slot width is $40 \mathrm{~cm}$ and $U_{f}$ is 5 or $10 \mathrm{~m} / \mathrm{s}$. Thus, the air flow sucked into the slot is $2 \%$ when $U_{f}$ is 5 or $10 \mathrm{~m} / \mathrm{s}$.

\subsection{Effect of the leak slot}

The best position of the leak slot, as presented in Fig. 1 , is just before the entry of the test section. However, an iron beam is in that position in our wind tunnel. Thus, the floor from $x=-80$ to $-120 \mathrm{~cm}$ is clipped, and the slot is installed there. It is possible to fill the slot with a cover when the slot is not used. Grating is attached under the slot to prevent falling accidents. The wind velocity after the slot installation is measured by the same method as described in section 2.2 .

In the distribution of $U$ at the height of $5 \mathrm{~cm}$ depicted in Fig. 6, the high-velocity region found along the line of $y=+20 \mathrm{~cm}$ in Fig. 3 is not seen. The low velocity regions still exist along the line of $y=+60 \mathrm{~cm}$ and that of $y=-60 \mathrm{~cm}$ for $x \geq 5 \mathrm{~m}$. However, the improvement in $y$-directional uniformity is remarkable for $x<5 \mathrm{~m}$. Figure 6 also depicts the distributions of $U$ at other heights. In the layers with heights of $10 \mathrm{~cm}$ or less, wind velocity contours that meander less than before the slot installation indicate that the development of the boundary layer is more uniform than before. Though the distributions of $U$ over the height of $30 \mathrm{~cm}$ are the same as those indicated in Fig. 3, the height of the boundary layer has reached $5 \mathrm{~cm}$ at $x=3.5 \mathrm{~m}$, and exceeds $10 \mathrm{~cm}$ for all $x \geq 9 \mathrm{~m}$. The boundary layer height is lower than that before the slot installation because boundary layer development is reset by leakage from the slot.

The distributions of the mean flow deflection angle depicted in Fig. 6 are the same as in Fig. 3, except that the area in which the deflection angle exceeds $1.0^{\circ}$ is reduced in the layers of $10 \mathrm{~cm}$ height and less. The deflection of the flow is improved only slightly by the slot.

Comparing $U$ at $x=2.0 \mathrm{~m}$ and $z=5 \mathrm{~cm}$ after the slot installation with that before the installation, Fig. 7 reveals a notable effect of the boundary layer leak slot. After the installation, $U$ is almost constant around its average of $4.9 \mathrm{~m} / \mathrm{s}$. Deviation from the average is within only $2.0 \%$. The increased wind velocity at a height of $5 \mathrm{~cm}$ after the installation is the result of the descent of the upper air with a larger velocity caused by the lower air runoff from the slot. Figure 7 compares the turbulence intensity $\sigma_{u} / U$ with that before the installation at the same position. The values after 
$U$
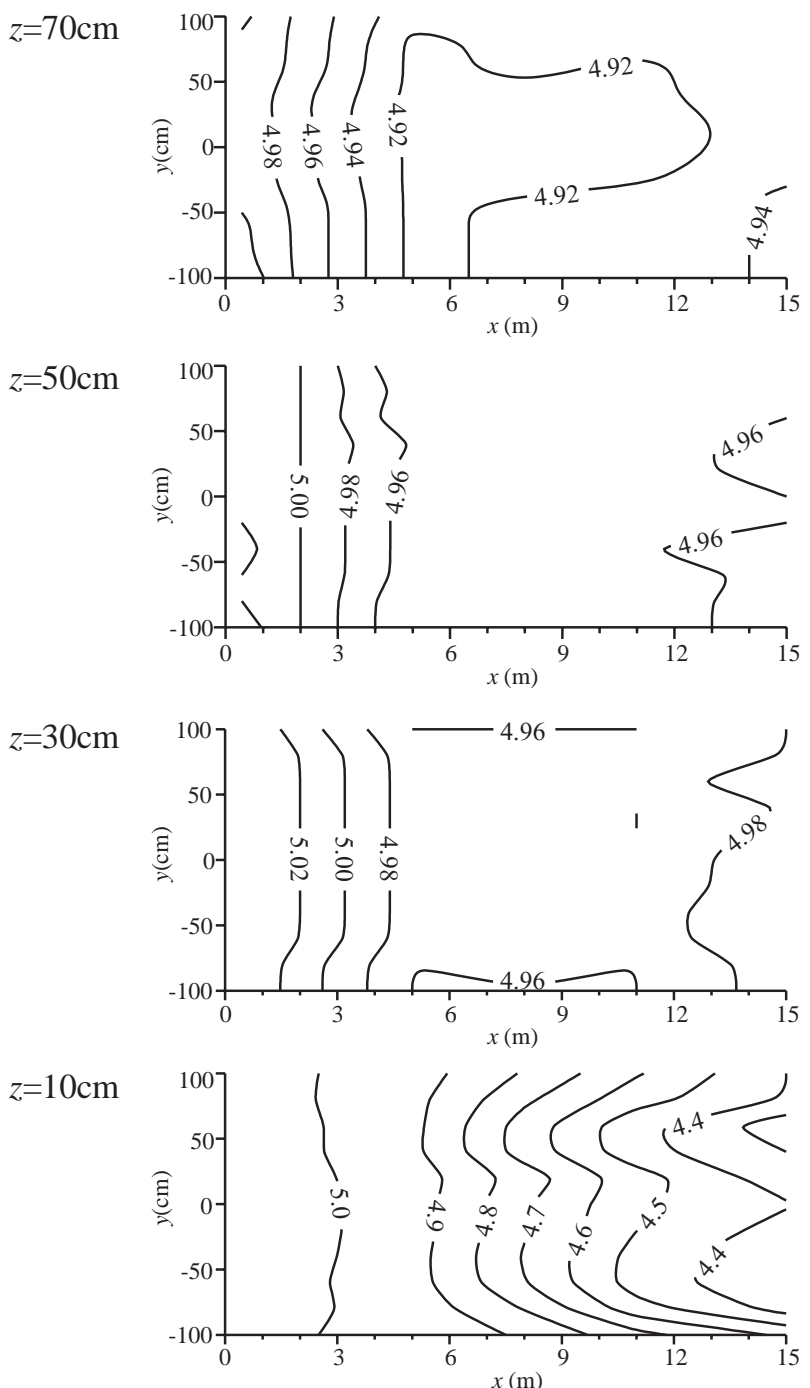

$z=5 \mathrm{~cm}$

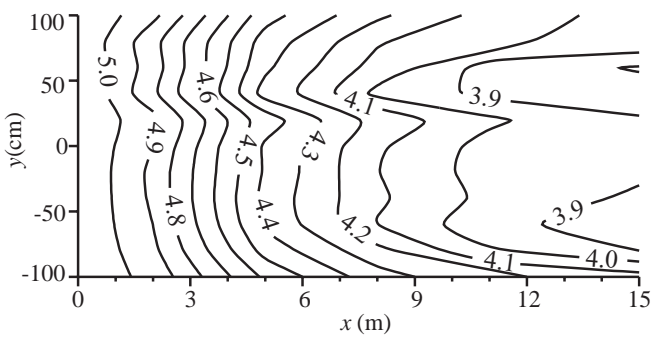

$D$
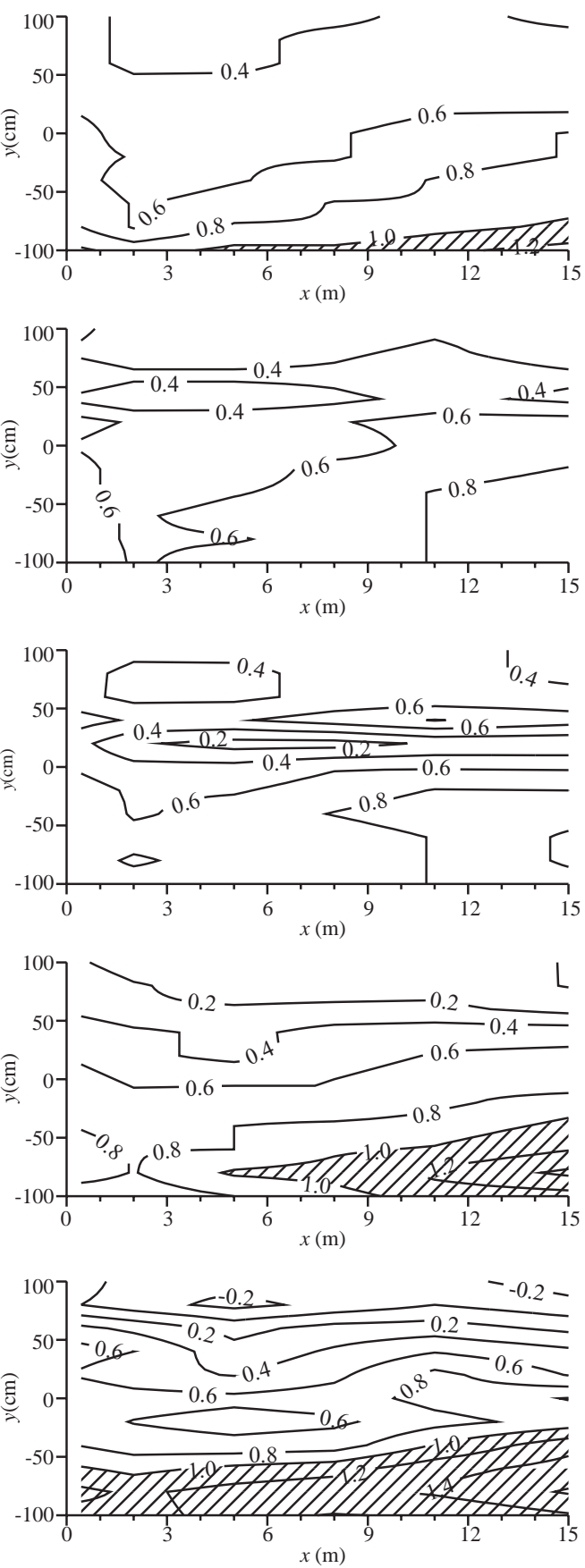

Fig. 6 Same as Fig. 3 but after boundary layer leak slot installation.

installation are smaller than those before, indicating that the slot discharges the boundary layer windward without disturbing the flow.

Uniformity at the height of $5 \mathrm{~cm}$ is illustrated in Fig. 8 . The values of $E$ for $x \leq 2 \mathrm{~m}$ after slot installation are much smaller than those before installation. However, the difference is negligible for $x \geq 5 \mathrm{~m}$, indicating that the slot improves flow uniformity for $x<5 \mathrm{~m}$. Since no measure was taken for the floor surface, $E$ increases with $x$ and reaches the same value as before.

\section{Summary and conclusions}

A boundary layer leak slot is devised to improve the flow quality in an open return wind tunnel. The non-uniform wind velocity distribution near the floor surface in the test section is expected to be improved by discharging the boundary layer upstream of the test section. The features of the slot are that the forcible exhaust, adopted in many automobile wind tunnels, is not used, and its low-cost implementation of just cutting a slot in the floor. The slot is tested in MRI's large meteorological wind tunnel. Before 

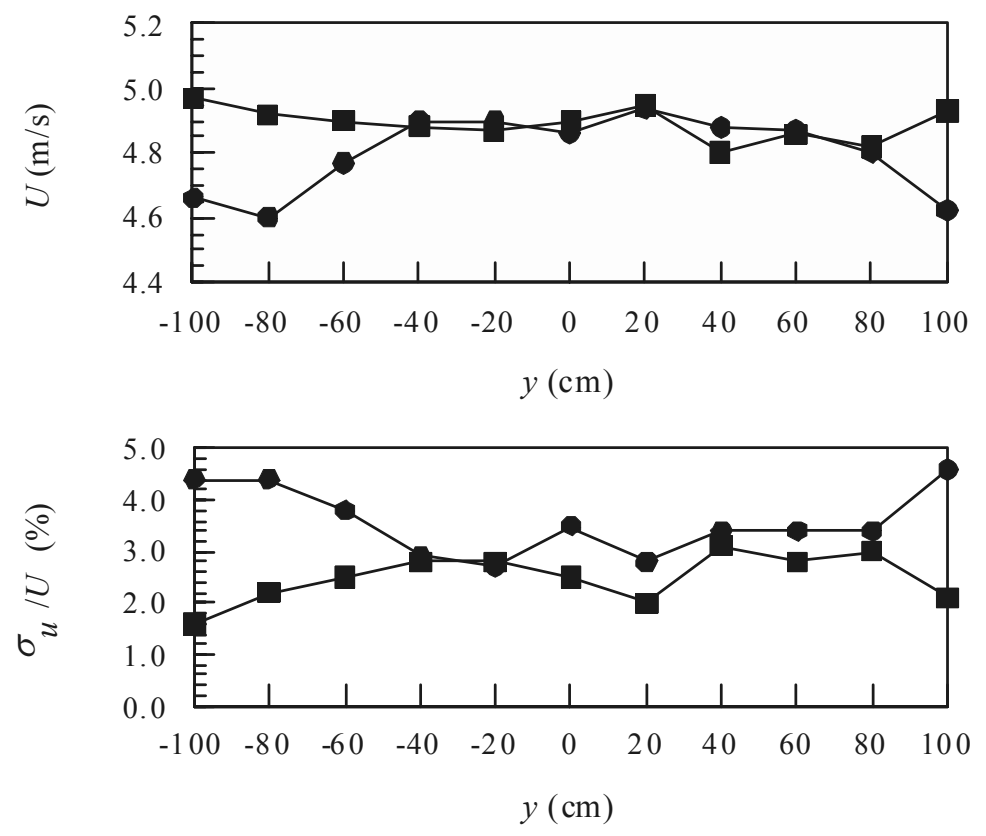

Fig. 7 Comparison of $U$ and $\sigma_{u} / U$ before and after slot installation. The values at $z=5 \mathrm{~cm}$ on the line from $y=-100$ to $+100 \mathrm{~cm}$ at $x=2.0 \mathrm{~m}$ are presented. The filled circles represent the values before installation, and the squares indicate the values after installation.

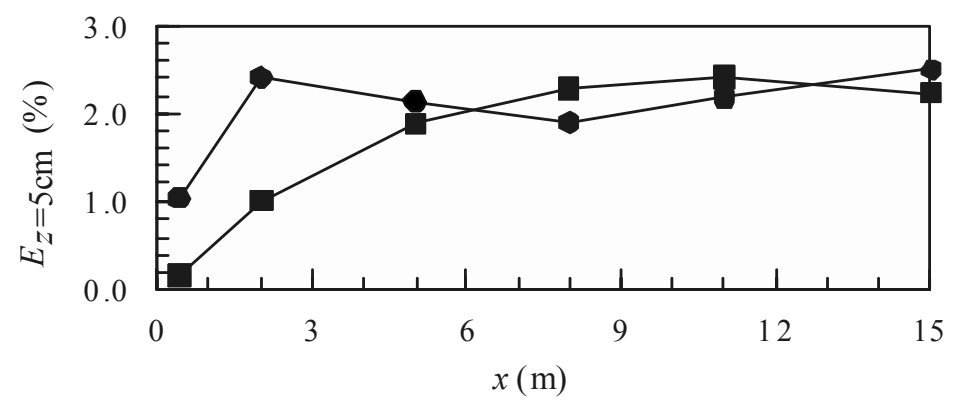

Fig. 8 Comparison of $E$ at $z=5 \mathrm{~cm}$ before and after slot installation. The filled circles represent the values before slot installation, and the squares represent those after installation.

slot installation, the wind velocity in the first 10 -cm layer nearest the floor surface of the test section is not uniform in the cross-direction to the centerline of the wind tunnel. The maximum deviation from the mean wind velocity at $5 \mathrm{~cm}$ over the surface and $2 \mathrm{~m}$ downwind from the upwind end of the test section is $4.2 \%$, when the wind tunnel flow velocity is $5.0 \mathrm{~m} / \mathrm{s}$. The flow near the centerline of the test section is deflected about $0.5^{\circ}$ from the centerline. The area in which the deflection angle exceeds $1^{\circ}$ is determined.

Defining the slot width as the streamwise opening length, the most effective slot width is determined to be $40 \mathrm{~cm}$ by an experiment in which the temporary slot width is changed from $0 \mathrm{~cm}$ to $100 \mathrm{~cm}$ for three free flow velocities $(1.0,5.0$, and $10.0 \mathrm{~m} / \mathrm{s})$.

The wind velocity in the test section is measured again after the installation of the slot, setting the wind tunnel flow velocity at $5.0 \mathrm{~m} / \mathrm{s}$. The result indicates that the wind velocity uniformity in the cross- direction to the wind tunnel centerline is remarkably improved in the upper reaches of the test section. The deviation from the mean wind velocity at $5 \mathrm{~cm}$ over the surface and $2 \mathrm{~m}$ downwind from the upwind end of the test section is decreased within $2 \%$. In contrast, improvement is not clear in the lower reaches. This deterioration of uniformity is caused by irregular floor surface roughness resulting from long-time use. Thus, it is necessary to smooth the test section floor surface to further improve flow quality. Though the deflection angle of the flow is improved only a little, the area over $1^{\circ}$ deflection is decreased. Therefore, it can be concluded that the boundary layer leak slot is an effective low-cost method of improving flow quality in an open return wind tunnel.

\section{Acknowledgements}

The author would like to thank Ebara Corporation for producing and installing the boundary layer leak slot, and for making the tables for the test.

\section{References}

Barlow, J B., W. H. Rae, and A. Pope, 1999: Low-speed wind 
tunnel testing, 3rd edition. A Willey- Interscience publication, N.Y., 713p.

Ishihara, Y., 2002: Aerodynamics of passenger cars. Nagare, 21, 62-67. In Japanese.

Kinoshita, N., 2003: Nonuniform distribution of high-frequency turbulence in the un-stable boundary layer. Boundary-Layer Meteorol., 106, 61-91.

Uchida, E., 1980: Introduction of new equipment in the Meteorological Research Institute. Tenki, 27, 536-577. In Japanese.

\title{
境界層漏出スロットの開放環流型気象風洞測定胴気流の 品質改善に対する効果
}

\author{
木下 宣幸
}

開放環流型風洞の気流品質を改善するため境界層漏出スロットを考案し、気象研究所の大型気象風洞で試験した。このスロッ 卜の特徵は多くの自動車風洞で採用されているような強制排出を用いない点にある。開口部の流れ方向の長さでスロットの幅を 定義し、この幅を Ocmから 100cmまで変える実験によって、改善に最も効果的な幅は 40 cmと決まった。測定胴の上流に境界層漏 出スロットを設置すると、風洞の中心軸に直交する方向での風速の一樣性は測定胴の上流部分で著しく改善された。一方、下流 では改善は顕著でなかった。下流での一樣性の悪化は長年の使用で床面上に不規則な粗さが生じたことによるものである。境界 層漏出スロットは開放環流型風洞の気流品質を改善するのに効果的で低コストな方法であると結論できる。 